Kong. Res. J. 2(1) : 115-117, 2015

ISSN 2349-2694

Kongunadu Arts and Science College, Coimbatore.

\title{
IMPACT OF PESTICIDE METHOXYCHLOR ON PROTEIN CONTENT IN THE FRESH WATER FISH, CYPRINUS CARPIO
}

\author{
Vasanthi. J*. and S. Binukumari \\ Department of Zoology, Kongunadu Arts and Science College, Coimbatore. \\ *E.mail: vasanthijraman@gmail.com
}

\begin{abstract}
Fishes are very sensitive to a wide variety of toxicants in water, various species of fish show uptake and accumulation of many contaminants or toxicants such as pesticides. The fresh water fish, Cyprinus carpio was exposed to methoxychlor and the median lethal concentration was found to be $0.42 \mathrm{ppm}$. After sublethal exposure tissues such as gill, liver, kidney, muscle and brain were sacrificed and analysed for protein content.
\end{abstract}

Key words: Cyprinus carpio, pesticide, fresh water fish.

\section{INTRODUCTION}

Pesticides have brought tremendous benefits to mankind by increasing food production and controlling the vectors of man and animal diseases. At the same time use of these pollutants has posed potential health hazards to the life of fishes. Pesticides are major cause of concern for aquatic environment because of their toxicity, persistency and tendency to accumulate in the organisms (Joseph and Raj, 2010). Pesticides are mostly non-selective, widespread applied, possess toxic properties and in some cases are very refractory. These features entitle pesticides to be one of the most fearful group substances as far as biological communities and humans are concerned.

Most of the pesticides of both plant origin and chemical applied in agricultural field reach water bodies through runoff affecting aquatic flora and fauna specially fishes. The lipophilicity of synthetic pesticides indicates that these chemicals will be absorbed by fish even from very low concentrations in water (Hill, 1989). Persistent chemical molecules with long half-life periods found in chemicals pose a threat to fish and also to the human population consuming the affected fish (Bouregeois et al., 1993; Nayak et al., 1995; Kalavathy et al., 2001; Saravanan et al., 2003; Selvarani and Rajamanickam, 2003 and Park et al., 2004).

\section{MATERIALS AND METHODS}

They were collected from the Mettur fish farm stocked and acclimatized for a time period of 10-15 days in the laboratory conditions in glass aquaria containing dechlorinated water. The water of the aquarium was aerated continuously through stone diffusers connected to a mechanical air compressor. Water temperature ranged between 22 $\pm 6^{\circ} \mathrm{C}$ and the $\mathrm{pH}$ was maintained between 6.1 and 8.4. Fish were fed twice daily alternately with rice bran and oil cakes.For the present study, matured adult fishes were exposed to different concentrations viz $\mathrm{LC}_{50}$ of Methoxychlor for short term (24, 48, 72 and 96 hours) and long term (10, 20 and 30 days) continuously. Seven groups of ten fishes for each concentration of the pesticides were used. In these aquaria water was replaced daily with fresh treatment of pesticides. Each experiment was accompanied by its respective control.

Methoxychlor is an organochlorine pesticide that was developed as a substitute for DDT. Methoxychlor has been used as a pesticide on pets, livestock, crops, gardens and in animal feed (Palanza et al., 2001; Magliulo et al., 2002). Appropriate narrow range of concentration was used to find the median lethal concentration, using a minimum of 10 fishes for each concentration and the mortality was recorded for every $24 \mathrm{hrs}$ upto $96 \mathrm{hrs}$. It was found as $0.42 \mathrm{ppm}$ for $96 \mathrm{hrs}$, using probit analysis method (Finney, 1971). From the stock solution various sublethal concentrations were prepared for bioassay studies.

At the end of each exposure period, fishes were sacrificed and tissues such as gill, liver, kidney, muscle and brain and were dissected and removed. The tissues (10 mg) were homogenized in $80 \%$ methanol, centrifuged at $3500 \mathrm{rpm}$ for 15 minutes and the clear supernatant was used for the analysis of protein content. Total protein concentration was estimated by the method of Lowry et al. (1951).

\section{RESULTS AND DISCUSSION}

Proteins occur in the body in the form of amino acids and other metabolites, which serve as building blocks of the body. Hence, protein content of the cell is considered to be an important tools for 
evaluation of the physiological standards. Several authors have reported alterations in total proteins and their metabolites in aquatic organisms exposed to toxicants (Ahmed et al., 1997).

The reduction in protein content under effluent stress noticed in the present study may be attributed

Table 1. Changes in the protein content in the tissues of Cyprinus carpio on short term exposure due to methoxychlor.

\begin{tabular}{|c|c|c|c|c|c|}
\hline \multirow{2}{*}{$\begin{array}{c}\text { Sample } \\
\text { (mg/g wet tissue) }\end{array}$} & \multicolumn{5}{|c|}{ Exposure Periods } \\
\hline & Control & $24 \mathrm{hrs}$ & $48 \mathrm{hrs}$ & $72 \mathrm{hrs}$ & 96 hrs \\
\hline Gill & $23.50 \pm 0.09$ & $21.36 \pm 0.10$ & $19.11 \pm 0.02$ & $18.36 \pm 0.06$ & $15.77 \pm 0.05$ \\
\hline$\%$ change & & $9.10 \downarrow$ & $18.68 \downarrow$ & $21.87 \downarrow$ & $32.89 \downarrow$ \\
\hline Liver & $25.61 \pm 0.06$ & $25.35 \pm 0.05$ & $24.87 \pm 0.10$ & $22.90 \pm 0.05$ & $22.76 \pm 0.07$ \\
\hline$\%$ change & & $1.01 \downarrow$ & $2.88 \downarrow$ & $10.58 \downarrow$ & $11.12 \downarrow$ \\
\hline Kidney & $19.38 \pm 0.03$ & $19.06 \pm 0.04$ & $18.32 \pm 0.30$ & $17.45 \pm 0.06$ & $17.20 \pm 0.05$ \\
\hline$\%$ change & & $1.65 \downarrow$ & $5.46 \downarrow$ & $9.95 \downarrow$ & $11.24 \downarrow$ \\
\hline$\%$ change & & $1.64 \downarrow$ & $4.22 \downarrow$ & $5.73 \downarrow$ & $8.22 \downarrow$ \\
\hline Brain & $14.59 \pm 0.05$ & $13.97 \pm 0.11$ & $13.45 \pm 0.08$ & $12.93 \pm 0.01$ & $12.66 \pm 0.18$ \\
\hline$\%$ change & & $4.24 \downarrow$ & $7.81 \downarrow$ & $11.37 \downarrow$ & $13.22 \downarrow$ \\
\hline
\end{tabular}

Values are mean \pm SD, n=5, Figures in Parenthesis are percentage decrease over control.

* - Significant at 5\%(t<0.05) ** - Significant at $1 \%(\mathrm{t}<0.01) \quad$ NS - Non Significant

Table 2. Changes in the protein content in the tissues of Cyprinus carpio on long term exposure due to methoxychlor.

\begin{tabular}{|c|c|c|c|c|}
\hline \multirow{2}{*}{$\begin{array}{c}\text { Sample } \\
\text { (mg/g wet tissue) }\end{array}$} & \multicolumn{4}{|c|}{ Exposure Periods } \\
\hline & Control & 10 days & 20 days & 30 days \\
\hline Gill & $23.50 \pm 0.09$ & $13.98 \pm 0.01$ & $10.45 \pm 0.07$ & $9.78 \pm 0.13$ \\
\hline$\%$ change & & $40.51 \downarrow$ & $55.53 \downarrow$ & $58.38 \downarrow$ \\
\hline Liver & $25.61 \pm 0.07$ & $20.76 \pm 0.04$ & $20.07 \pm 0.03$ & $18.32 \pm 0.16$ \\
\hline$\%$ change & & $18.93 \downarrow$ & $21.63 \downarrow$ & $28.46 \downarrow$ \\
\hline Kidney & $19.38 \pm 0.11$ & $16.54 \pm 0.05$ & $16.11 \pm 0.01$ & $15.08 \pm 0.08$ \\
\hline$\%$ change & & $14.65 \downarrow$ & $16.87 \downarrow$ & $22.18 \downarrow$ \\
\hline$\%$ change & & $13.12 \downarrow$ & $15.43 \downarrow$ & $17.58 \downarrow$ \\
\hline Brain & $14.59 \pm 0.05$ & $12.08 \pm 0.02$ & $11.75 \pm 0.06$ & $11.00 \pm 0.03$ \\
\hline$\%$ change & & $17.20 \downarrow$ & $19.46 \downarrow$ & $24.60 \downarrow$ \\
\hline
\end{tabular}

Values are mean \pm SD, $n=5$, Figures in Parenthesis are percentage decrease over control.

* - Significant at 5\% $(\mathrm{t}<0.05) \quad * *$ - Significant at $1 \%(\mathrm{t}<0.01) \quad$ NS - Non Significant

\section{REFERENCES}

Ahmed, R., M. Elumalai and M.P. Ezhilarasi Balasubramanian, (1997). Individual and combined effect of copper and chromium on oxygen consumption and phophatases of a marine edible crab, Scyil serrate. Biomed. 55: 147-179.

Bouregeois, D.P., J. Gaudet, P. Deveau and N. Maller, (1993). Micro extraction of organophosphorus pesticides from environmental water and analysis by gas chromatography. Bull. Environ. Contam. Toxicol. 50: 433-440

Finney, D.J. (1971). Probit analysis, $3^{\text {rd }}$ edition. (London: Cambridge University Press). 20.

Hill, J.R. (1989). Aquatic organisms and pyrethroids. Pesticide Sci. 27: 429-465.

Jha, B.S. (1991). Alterations in the protein and lipid contents of intestine, liver and gonads in the lead exposed fresh water murrel, Channa punctatus (Bloch). J. Ecobio. 12: 9-34.

Joseph, B. and S.J. Raj, (2010). Effect of curacron toxicity on the total serum protein content of Cyprinus carpio. Toxicol. Environ. Chem. 92: 1889-1893.

Kalavathy, K., A.A. Sivakumar and R. Chandran, (2001). Toxic effect of the pesticide Dimethoate on the fish, Sarotherodon mossambicus. J. Ecol. Res. Biocons. 2(1-2): 27-32.

Lowry, O.H., N.J. Rose Brough, L. Farr and R.J. Randall, (1951). Protein measurements with the folin phenol reagent. J. Biol. Chem. 193: 265275.

Magliulo, L., M.P. Schreibman, J. Cepriano and J. Ling, (2002). Endocrine disruption caused by two common pollutants at 'acceptable' concentrations. Neurotoxicol. Teratol. 24: 7179. 
Nayak, A.K., R. Raha and A.K. Das, (1995). Organochlorine pesticides in middle stream of the Ganga River, India. Bull. Environ. Contam. Toxicol. 54: 68-76.

Palanza, P., S. Parmigiani and F.S. Vomsaal, (2001). Effects of prenatal exposure to low doses of diethylstilbestrol, o.p'-DDT and methoxychlor on postnatal growth and neurobehavioural development in male and female mice. Horm. Behav. 40: 252-265.

Park, D., M.D. Minor and C.R. Propper, (2004). Toxic response of endosulfan to breeding and non breeding female mosquito fish. J. Environ. Biol. 25: 119-124.

Saravanan, T.S., M.A. Mohamed, R. Chandrasekhar and M. Sundramoorthy, (2003). Fresh water fishes as indicators of Cauvery River pollution. J. Environ. Biol. 24: 381-389.

Selvarani, D. and C. Rajamanickam, (2003). Toxicity of PCB 1232 on mitochondria of fish, Arius caelatus (Valenciennes). Indian. J. Exp. Biol. 41: 336-340. 